\title{
ARTIGOS \\ FREE CULTURE MEDIA OF GROWTH REGULATORS ON MICROPROPAGATION OF GRAPEVINE (VITIS LABRUSCA L.) 'BORDÔ' CULTIVAR THROUGH NODAL SEGMENTS
}

\author{
Bettoni, JC', Costa $\mathrm{MD}^{* *}$, Gardin JPP ${ }^{* * *}$,Kretzschmar AA ${ }^{* * * *}$, Souza JA ${ }^{* * * *}$, Passos JFM ${ }^{* * * * *}$
}

\begin{abstract}
The micropropagation is an important biotechnological tool for obtaining and maintaining mother grapevine plants with high quality plant health. The objective was to evaluate the establishment and multiplication in vitro and ex vitro acclimatization of grapevine cultivate Bordô in different culture media without adding growth regulators. Grapevine nodal segments were cultured in five culture media formulations without adding growth regulators. It was evaluated the number of leaves and roots, length of roots and shoots, replication rate, relative chlorophyll index, percentage of regenerated and rooted plants, dry biomass of shoot, root and total plants grown in vitro and after acclimatization. In vitro propagation of grapevine Bordô through nodal segments provided high rates of regeneration and rooting. High survival rates were obtained in the acclimatization of Bordô. Considering all the varia-

\footnotetext{
"MSc in Plant Production at Universidade Estadual de Santa Catarina; PhD in progress in Plant Production at Universidade Estadual de Santa Catarina; jcbettoni@gmail.com

${ }^{* *} \mathrm{PhD}$ in Plant Genetic Resources at Universidade Federal de Santa Catarina; MSc in Agroecosystems at Universidade Federal de Santa Catarina; murilodc@epagri.sc.gov.br

${ }^{* * *} \mathrm{PhD}$ in Agronomy (Plant Physiology) at Universidade Federal de Lavras; MSc in Plant Physiology at Universidade Federal de Pelotas; joaogardin@epagri.sc.gov.br

${ }^{* * * *} \mathrm{PhD}$ in Plant Science at Universidade Federal do Rio Grande do Sul; MSc in Temperate Fruit Growing at Universidade Federal de Pelotas; aikeanneliese@yahoo.com.br

***** Graduated in Biology at Universidade do Alto Vale do Rio do Peixe; MSc in progress in Plant Production at Universidade Estadual de Santa Catarina; julianaaparecidasouza@gmail.com

${ }^{* * * * * *} \mathrm{PhD}$ in Genetics and Molecular Biology at Universidade Federal do Rio Grande do Sul; MSc in Soil Science at Universidade Estadual de Santa Catarina; joaopassos@epagri.sc.gov.br
} 
bles, culture media Roubelakis and Zlenko showed the best growth rates and development for shoots and roots, and in vitro multiplication rate of Bordô grapevine cultivar.

Keywords: In vitro propagation. Vegetative propagation. Vitis.

\title{
Meios de cultura livres de reguladores de crescimento na micropropagação da videira (Vitis labrusca L.) cultivar 'Bordô' através de segmentos nodais
}

\author{
Resumo
}

A micropropagação é uma importante ferramenta biotecnológica para a obtenção e manutenção de plantas matrizes de videira de alta qualidade fitossanitária. O objetivo do trabalho foi avaliar o estabelecimento e a multiplicação in vitro e a aclimatização ex vitro da videira $\mathrm{cv}$. Bordô em diferentes meios de cultura sem a adição de reguladores de crescimento. Segmentos nodais foram cultivados em cinco formulações de meios de cultura sem adição de reguladores de crescimento. Foram avaliados o número de folhas e de raízes, comprimento da maior raiz e da parte aérea, taxa de replicação, índice relativo de clorofila, biomassa seca da parte aérea, radicular e total, porcentagem de plantas regeneradas e enraizadas, de plantas cultivadas in vitro e após aclimatização. A propagação in vitro da cv. Bordô através de segmentos nodais proporcionou elevadas taxas de regeneração e enraizamento. Elevadas taxas de sobrevivência foram obtidas na aclimatização da cv. Bordô. Considerando todas as variáveis analisadas, as formulações salinas Roubelakis e Zlenko proporcionaram o melhor crescimento e desenvolvimento da parte aérea e radicular e taxa de multiplicação in vitro da cultivar de videira Bordô.

Palavras-chave: Propagação in vitro. Propagação vegetativa. Vitis.

\section{INTRODUCTION}

In the last decade, following global trends, the grape and wine national market is undergoing a processing resulting from the Brazilian consumer habits change. In the season 2014/2015 domestic production was 1.436 .074 tons; that amount $46.89 \%$ of the grapes were aimed at production of wine, juices and derivatives and $53.11 \%$ for fresh consumption. ${ }^{1}$ The search for a healthy diet associated with the attractive flavor of grape juice makes this market an interesting income option for Brazilian grape growers.

In southern Brazil, viticulture consolidated with the cultivation of American origin grapes. The Bordô grape (Vitis labrusca L.), introduced in Rio Grande do Sul in 1839, is one of the cultivars, which is due to several factors, such as high productivity, use of diversity (wine, juice, table grape, jelly and vinegar) and rusticity. ${ }^{2}$ So, consumption is given in different ways, the must of grapes Bordô is considered the dye base of juice and Brazilian table wine. Also creates a typical wine with aroma and fruity and foxy flavor, appreciated by a particular group of consumers.

To ensure the longevity of the orchard and the quality of the grapes produced, the acquisition of propagative materials with good phytosanitary conditions is required. However, the availability of 
free of pathogens materials is a limiting factor for the sustainability of agricultural production and the permanence in the activity. ${ }^{3}$

In this sense, micropropagation techniques are important tools for obtaining and maintaining stock plants of good quality phytosanitary. ${ }^{4}$ The process enables the mass multiplication of plants and the formation of free virus matrices; besides preservation materials of interest in an aseptic environment. ${ }^{5,6,7}$

The culture media, responsible for supplying the basic nutritional needs for growth and development of explants is a relevant factor in the micropropagation process. ${ }^{8}$ Thus, the choice of a suitable salt formulation has a direct relationship with the successful development of in vitro cultures. ${ }^{3,8}$ Published protocol with Vitis suggest the addition of plant growth regulators in the culture media, particularly from the group of the cytokinins, to promote multibrotation. ${ }^{9}$ However, inadequate concentrations of cytokinin can promote the formation of anomalous shoots and multiplication in the form callus, ${ }^{8}$ which is undesirable for vegetative propagation protocols, especially the risk of induced somaclonal mutation. Recent study described by Bettoni et al., ${ }^{3}$ with Vitis, demonstrate that free salt formulations of growth regulators provided high in vitro multiplication rates and grapevines had root formation in various free culture media growth regulators and or specific phase for rooting. Thus, the aim of this study was to evaluate the establishment and multiplication in vitro in different culture media without adding growth regulators. and ex vitro acclimatization of grape cv. Bordô.

\section{MATERIALS AND METHODS}

Mother plants from Bordô grape (Vitis labrusca L.) were kept in greenhouse for providing explants. Experiments were performed in completely randomized design, with five treatments (saline formula) and thirty repetitions for each treatment in the evaluations during in vitro phase, and ten repetitions during acclimatization phase.

It was tested saline formulation proposed by Galzy, Haffner and Compan, ${ }^{6}$ Roubelakis-Angelakis and Zivanovitc, ${ }^{10} \mathrm{C}_{2} \mathrm{D},{ }^{11} \mathrm{DSD} 1^{12}$ and Zlenko, Troshin and Kotikov ${ }^{13}$ for in vitro grapevine cultivation, supplemented with $20 \mathrm{~g} \mathrm{~L}^{-1}$ of sucrose and $7 \mathrm{~g} \mathrm{~L}^{-1}$ of agar, without growth regulators.

2 -cm-nodal segments, with a single bud were used as explants source for in vitro cultivation. Under aseptic conditions, nodal segments were superficially sterilized, embedded in $70 \%$ alcohol (v/v) for 15 seconds and rinsed two times in sterile water; after, they were immersed in $80 \%$ sodium hypochlorite solution (v/v) and $0.1 \%$ Tween $20(\mathrm{v} / \mathrm{v})$ during 15 minutes and rinsed three times in sterile water. Explants were transferred into the test tubes (110 mm X $23 \mathrm{~mm})$ with $10 \mathrm{~mL}$ of different culture media.

Cultures were maintained in the test room at $25^{\circ} \mathrm{C} \pm 2{ }^{\circ} \mathrm{C}$ during the fourth days in the dark, and after for a photoperiod of 16 hours of light per day ${ }^{-1}$ and luminous intensity of $50 \mu \mathrm{mol} \mathrm{m}^{-2} \mathrm{~s}^{-1}$. Sub-crops were done each 45 days, segmenting sprouts in nodal segments of $1 \mathrm{~cm}$ length with a single bud. After the second sub-crop, in vitro cultures were maintained in growth for 60 days and were 
evaluated for number of leaves and roots, length of the bigger root and the aerial part, replication rate, chlorophyll index, dry matter from aerial parts and roots after drying in the oven at $60{ }^{\circ} \mathrm{C}$ for 48 hours, percentage of regenerated and rooted plants.

Replication rate was obtained by counting explants number which are originated when the material is replicated. For indirect measures of chlorophyll (chlorophyll index) in SPAD value, readings from adaxial face of the leaf located on the medium part of each bud, selecting completely expanded leaves through Handheld Chlorophyll Gauge SPAD-502 (Soil Plant Analysis Development, Konica Minolta $^{\oplus}$, Japan). Readings values performed with the gauge were calculated based on the quantity of transmitted light by the leaf on two wavelengths; the light that has passed through the leaf reaches a receptor which converts light on analog signals, and those ones on digital signals that are used to calculate SPAD values. ${ }^{14}$

Ex vitro acclimatization was performed with the third sub-cultures after 60 days in in vitro growing. Roots were washed in water and pruned $(2 \mathrm{~cm}$ length); aerial part was maintained with 2 or 3 basal leaves. Buds were transferred to honey-combed trays with 72 cells $(100 \mathrm{~mL})$ containing sterilized substrate at $121{ }^{\circ} \mathrm{C}$ for 1 hour with Dystroferric Red Nitosol, sand and commercial substrate Tecnomax $(1: 1: 1, \mathrm{v} / \mathrm{v} / \mathrm{v})$. Trays were packed into plastic boxes, covered with glass and put in an acclimatization room during 60 days. Analyzed variables were the same as the experiments performed in vitro, exception to replication rate.

Statistical models were considered according to the nature of the variable response. For the variables Roots Number, Leaves Number and Replication Rate, it was used Poisson's distribution. Model prepositions were verified using Kolmogorov-Smirnov's Tests for normality of residuals, and Bartlett's test for variance homogeneity.

In order to verify the model adjustment, it was used normal plot with simulated envelopes for deviance residual. ${ }^{15}$ Data were submitted to variance analysis and, if significant, averages were compared by Tukey's test at 5\% significance level in R environment. ${ }^{16}$

\section{RESULTS AND DISCUSSION}

Morphological studies related with anatomical characteristics of grapevine plants in vitro were described by several authors, ${ }^{3,17-19,6}$ and variations of evaluation results usually are related to the formulations of culture media and genotype used.

Independently of the saline formulation of each nutritive media, in vitro cultures of Bordô cultivar showed high potential for regeneration and rooting, so that all explants that were placed in vitro regenerated and virtually all had root formation, except $\mathrm{C} 2 \mathrm{D}$ formulation, which occurred the rooting of $85 \%$ of inoculated explants (Table 1). These results suggest that there is no need of use of growth regulators in culture media to promote multiplication, rooting or specific phase for rooting. Similar results were described by Biasi, Passos and Pommer ${ }^{19}$ and other authors ${ }^{8}$ in in vitro propagation of Jales and VR 043-43 grapevine rootstock, respectively, in saline formulations without growth regulators. 
For the variable number of leaves, no significant differences were observed among formulations. At the end of the third subculture was obtained an overall average of 6.1 leaves per explant (Table 1). These results are similar to those found by other research ${ }^{18}$ in in vitro propagation of VR 043-43 and SO4 grapevine rootstock, and lower than reported by researches ${ }^{20}$ with SO4, Riparia, Grav, 140Ru and Fercal rootstocks, that after 60 days of cultivation in DSD1 formulation obtained around 10 leaves per explant.

Roubelakis' formulation promoted greater number of roots, with average formation of 2.7 main roots per plant, not differing significantly from the ZL, DSD1and C2D formulations, which formed on average 2.1 roots per plant respectively (Table 1). Roubelakis-Angelakis and Zivanovitc, ${ }^{10}$ by comparing the Murashigee and Skoog $(\mathrm{MS})^{21}$ and Roubelakis formulations in micropropagation of 15 grapevine cultivars, found better development and increased formation of primary roots of in vitro plants in Roubelakis media.

Similarly to the previous variable, the greater length of roots occurred when cv. Bordô was cultivated in Roubelakis formulation $(12.5 \mathrm{~cm})$, which was higher than Galzy formulation and not different from the formulations ZL, DSD1 and C2D, that obtained on average a length of $10.3 \mathrm{~cm}$ (Table 1). Variations in genotype responses to different culture media associated substantially with the composition of the nutrient formulations. The same statement was reported in a study ${ }^{22}$ with evaluation of eight culture media in vitro propagation of cv. Red Globe, where different nutrient sources made up the formulations and exercised influence on the development of cultivar.

The aerial parts length of Bordô cultivar ranges from 3.8 and $4.7 \mathrm{~cm}$, no significant differences between the formulations of culture media (Table 1). These values are higher than those found in a study ${ }^{9}$ with the same cultivar, in different culture media formulations with and without growth regulators and lower than those found by other authors ${ }^{8,20}$ in the multiplication of grapevine rootstock in without growth regulators formulations. 
Table 1 - Number of leaves and roots, length $(\mathrm{cm})$ of the longest root and aerial part and replication rate (TR), relativachlorophyll index (IRC), dry matter $(\mathrm{mg})$ of roots and aerial part, total biomass $(\mathrm{mg})$, regeneration $(\mathrm{R})$ and rooting (E) of Bordô grapevine nodal segments cultivated in different culture media ${ }^{\dagger}$

\begin{tabular}{|c|c|c|c|c|c|c|}
\hline \multirow{2}{*}{$\begin{array}{l}\text { Culture } \\
\text { Media }\end{array}$} & \multicolumn{2}{|c|}{ Number } & \multicolumn{2}{|c|}{ Length $(\mathrm{cm})$} & \multirow[b]{2}{*}{$\mathrm{TR}$} & \multirow[b]{2}{*}{ IRC } \\
\hline & Leaves & Roots & Longer Root & $\begin{array}{c}\text { Aerial } \\
\text { Part }\end{array}$ & & \\
\hline Roubelakis & $6.2 \mathrm{a}$ & $2.7 \mathrm{a}$ & $12.5 \mathrm{a}$ & $4.4 \mathrm{a}$ & $5.2 \mathrm{a}$ & $26.9 \mathrm{ab}$ \\
\hline $\mathrm{ZL}$ & $6.1 \mathrm{a}$ & $2.2 \mathrm{ab}$ & $10.5 \mathrm{ab}$ & $4.2 \mathrm{a}$ & $5.2 \mathrm{a}$ & $26.2 \mathrm{ab}$ \\
\hline DSD1 & $6.3 \mathrm{a}$ & $1.8 \mathrm{ab}$ & $11.2 \mathrm{ab}$ & $4.7 \mathrm{a}$ & $5.4 \mathrm{a}$ & $23.9 \mathrm{~b}$ \\
\hline Galzy & $5.8 \mathrm{a}$ & $1.5 \mathrm{~b}$ & $8.7 \mathrm{~b}$ & $4.4 \mathrm{a}$ & $5.0 \mathrm{a}$ & $24.5 \mathrm{~b}$ \\
\hline $\mathrm{C} 2 \mathrm{D}$ & $6.2 \mathrm{a}$ & $2.2 \mathrm{ab}$ & $9.1 \mathrm{~b}$ & $3.8 \mathrm{a}$ & $4.5 \mathrm{a}$ & $29.2 \mathrm{a}$ \\
\hline Mean & 6.1 & 2.1 & 10.4 & 4.3 & 5.1 & 26.1 \\
\hline C.V. (\%) & 24.96 & 23.12 & 42.93 & 17.04 & 34.43 & 15.56 \\
\hline \multirow{2}{*}{$\begin{array}{l}\text { Culture } \\
\text { Media }\end{array}$} & \multicolumn{4}{|c|}{ Dry Matter (mg) } & \multirow{2}{*}{$\mathrm{R}(\%)$} & \multirow{2}{*}{ E (\%) } \\
\hline & Roots & Aerial Part & Total & omass & & \\
\hline Roubelakis & $14.9 \mathrm{a}$ & $27.9 \mathrm{a}$ & \multicolumn{2}{|c|}{$42.8 \mathrm{a}$} & 100.0 & 100.0 \\
\hline $\mathrm{ZL}$ & $12.7 \mathrm{ab}$ & $26.9 \mathrm{a}$ & \multicolumn{2}{|c|}{$39.7 \mathrm{ab}$} & 100.0 & 100.0 \\
\hline DSD1 & $14.0 \mathrm{a}$ & $32.2 \mathrm{a}$ & \multicolumn{2}{|c|}{$46.2 \mathrm{a}$} & 100.0 & 100.0 \\
\hline Galzy & $11.7 \mathrm{ab}$ & $30.6 \mathrm{a}$ & \multicolumn{2}{|c|}{$42.4 \mathrm{a}$} & 100.0 & 100.0 \\
\hline $\mathrm{C} 2 \mathrm{D}$ & $8.6 \mathrm{~b}$ & $30.9 \mathrm{a}$ & \multicolumn{2}{|c|}{$36.3 \mathrm{~b}$} & 100.0 & 85.0 \\
\hline Mean & 12.4 & 29.7 & \multicolumn{2}{|c|}{41.5} & 100.0 & 97.0 \\
\hline C.V. (\%) & 40.15 & 9.05 & \multicolumn{2}{|c|}{8.37} & ------ & ------ \\
\hline
\end{tabular}

Replication rate reflects the quantity of propagules derived from a single explant. As a reflection of 'number of leaves' and 'stem length' variables, no significant differences among formulations in relation to the rate of replication. When cultures of $\mathrm{cv}$. Bordô are pricked generate an average of 5.1 new plants (Table 1). On the contrary, some authors ${ }^{23}$ showed the influence of the composition of the culture media on the in vitro development deGrasset grapevine rootstock (Vitis champinii Planch.), and related formulations express effects on aerial growing rates which in turn are linked to the replication capacity of the inoculated explant. The results for the replication rate found in this study are higher than those evidenced by Krizan, Ondrusiková and Moudrá ${ }^{24}$ when multiplied Kober 5BB, 125AA Kober and Teleki 5C grapevine rootstocks in different culture media.

In relation to chlorophyll index, values of SPAD-502 reading showed culture media formulations influenced chlorophyll rate (Table 1). The highest chlorophyll indexes (IRC) were found when the Bordô cv. was cultivated on C2D, Roubelakis and ZL formulations, with IRC in the range of 26.2 to 29.2; saline formulation ZL and Roubelakis did not differ from culture media DSD1 and Galzy. Likewise, authors ${ }^{25}$ related the influence of culture media on Criolla Grande and Pedro Giménez grapevine culti-

\footnotetext{
${ }^{\dagger}$ Averages followed by the same letter in the column do not differ among them by Tukey test $(\mathrm{p}<0,005)$.
} 
vars, and the biggest values were found to Criolla Grande cultivated on $1 / 2 \mathrm{MS}$ formula. According to the authors, IRC of Cereza, Criolla Chica and Torrontés Riojano cultivars in different culture medium have varied from 23.3 to 31.2, similar to those described for Bordô cv. in investigated formulations. Results in this study can be explained by the difference on mineral constitution of saline formulations; nitrogen and magnesium contents are found in the investigated formulations and those which show higher IRC have higher concentration of these nutrients in the formula. Nitrogen and magnesium are nutrients that have participation on chlorophyll molecule synthesis and structure, therefore when there is an increment of those nutrient sources, higher chlorophyll contents are observed. ${ }^{26}$

In relation to the allocation of in vitro reserves, Bordô cv. showed around $90 \%$ of dry matter accumulation in the aerial part, without significant difference among the culture mediua (Table 1). Results are in accordance with those by Ribeiro ${ }^{27}$ and other authors, ${ }^{20}$ who observed higher accumulation of leaves and stem dry matter from Paulsen 1103 and VR 043-43 grapevine rootstocks and from Cabernet Sauvignon cv. in relation to roots dry matter.

The higher root dry matter accumulation of Bordô cv. was obtained when cultivating in Roubelakis and DSD1 formulations, with $14.9 \mathrm{mg}$ of dry roots, more than C2D formulation (8.6 mg) and without differing significantly from ZL and Galzy formulations, with an accumulation around $12 \mathrm{mg}$ of dry roots (Table 1). According to Silva and Doazan ${ }^{12}$ dry biomass, stem length and leaf area are the more reliable parameters evaluate in vitro development and multiplication of grapevine genotypes.

In the production of total biomass, the higher accumulation of dry matter were achieved when the cv. Bordô was cultivated in DSD1, Roubelakis and Galzy formulations, with average formation of $43.8 \mathrm{mg}$ of dry matter, differing from C2D formulation; ZL does not differ from the other formulations (Table 1). These values were higher than those related by Ribeiro, ${ }^{27}$ in evaluating culture media for in vitro propagation VR043-43 and Paulsen 1103 grapevine rootstocks and the Cabernet Sauvignon cv. and those reported by other researches ${ }^{18}$ (2003) at in vitro propagation of SO4 and Paulsen 1103 grapevine rootstocks, which after 60 days of in vitro culture in DSD1 formulation showed 34.8 and $35.6 \mathrm{mg}$ dry matter accumulation.

The acclimatization process of Bordô cultivar showed, after 60 days, survival above $85 \%$ in all saline formulations studied. Losses were found only for the C2D formulation in which only two plants did not survive the acclimation (Table 2). These results indicate the efficiency of the method that was used for the in vitro transfer of plants to ex vitro conditions. Working with the same cultivar, other authors ${ }^{28}$ compared different substrates for the acclimatization of plants cv. Bordô, they not found differences among different substrate formulations and survival ranged from $96 \%$ to $100 \%$. 
Table 2 - Number of leaves and roots, length $(\mathrm{cm})$ of the longest root and aerial part, relative chlorophyll index (IRC), dry mass (mg) of roots and aerial part, total biomass (mg) and survival index (TS) of acclimatized Bordô grapevine seedlings cultivated in different culture media ${ }^{\ddagger}$

\begin{tabular}{|c|c|c|c|c|c|}
\hline \multirow{2}{*}{$\begin{array}{l}\text { Culture } \\
\text { Media }\end{array}$} & \multicolumn{2}{|c|}{ Number } & \multicolumn{2}{|c|}{ Length (cm) } & \multirow{2}{*}{ IRC } \\
\hline & Leaves & Roots & Longer Root & Aerial Part & \\
\hline Roubelakis & $6.9 \mathrm{a}$ & $7.7 \mathrm{a}$ & $15.9 \mathrm{a}$ & $11.8 \mathrm{a}$ & $21.2 \mathrm{a}$ \\
\hline $\mathrm{ZL}$ & $6.6 \mathrm{a}$ & $7.5 \mathrm{a}$ & $14.3 \mathrm{a}$ & $11.3 \mathrm{ab}$ & $21.1 \mathrm{a}$ \\
\hline DSD1 & $6.8 \mathrm{a}$ & $7.2 \mathrm{a}$ & $14.4 \mathrm{a}$ & $10.4 \mathrm{bc}$ & $21.1 \mathrm{a}$ \\
\hline $\mathrm{C} 2 \mathrm{D}$ & $6.3 \mathrm{a}$ & $7.7 \mathrm{a}$ & $13.6 \mathrm{a}$ & $9.8 \mathrm{c}$ & $21.3 \mathrm{a}$ \\
\hline Galzy & $6.6 \mathrm{a}$ & $4.4 \mathrm{~b}$ & $14.4 \mathrm{a}$ & $10.2 \mathrm{bc}$ & $21.0 \mathrm{a}$ \\
\hline Mean & 6.6 & 6.9 & 14.5 & 10.7 & 21.1 \\
\hline C.V. (\%) & 13.70 & 38.73 & 20.36 & 19.95 & 6.96 \\
\hline \multirow{2}{*}{$\begin{array}{l}\text { Culture } \\
\text { Media }\end{array}$} & \multicolumn{4}{|c|}{ Dry Matter (mg) } & \multirow{2}{*}{ TS (\%) } \\
\hline & Roots & Aerial Part & \multicolumn{2}{|c|}{ Total Biomass } & \\
\hline Roubelakis & $51.6 \mathrm{a}$ & $167.9 \mathrm{a}$ & \multicolumn{2}{|c|}{$219.5 \mathrm{a}$} & 100.0 \\
\hline $\mathrm{ZL}$ & $41.5 \mathrm{ab}$ & $141.4 \mathrm{ab}$ & \multicolumn{2}{|c|}{$182.9 \mathrm{ab}$} & 100.0 \\
\hline DSD1 & $36.4 \mathrm{~b}$ & $125.7 \mathrm{ab}$ & \multicolumn{2}{|c|}{$162.2 \mathrm{ab}$} & 100.0 \\
\hline $\mathrm{C} 2 \mathrm{D}$ & $34.8 \mathrm{~b}$ & $111.5 \mathrm{~b}$ & \multicolumn{2}{|c|}{$146.4 \mathrm{~b}$} & 85.7 \\
\hline Galzy & $36.0 \mathrm{~b}$ & $129.9 \mathrm{ab}$ & \multicolumn{2}{|c|}{$165.9 \mathrm{ab}$} & 100.0 \\
\hline Mean & 40.1 & 135.3 & \multicolumn{2}{|c|}{175.4} & 97.1 \\
\hline C.V. (\%) & 12.78 & 38.00 & \multicolumn{2}{|c|}{32.52} & ------ \\
\hline
\end{tabular}

In relation to the effects of acclimatization environment on survival rate of Jales' grapevine rootstock, Biasi, Passos and Pommer ${ }^{19}$ observed plant survival from 92.5 to $100.0 \%$ which were acclimatized in an environment under misting, in opened and closed containers, respectively. Moreover, Dzazio, Biasi and Zanette ${ }^{29}$ comparing different substracts for '420- grapevine rootstock acclimatization, observed high survival rates regardless of the type of particulated substract. These researches and others relating ${ }^{3,30}$ high survival on grapevine acclimatization have showed ease grapevine adaptability on transferring in vitro to ex vitro conditions.

After acclimatization, it was possible to detect effects of formulations have on acclimatized plants (Table 2). For the variable number of leaves, no significant differences were observed between the formulations. Formation occurred on average of 6.6 leaves per plant, these results are superior to those presented by other authors researched ${ }^{28}$ with the same cultivar.

Greater amounts of roots are formed when plants Bordô cv. were cultivated previously with Roubelakis, ZL, DSD1 and C2D formulations, on average 7.6 roots per plant, differing significantly from Galzy formulation which forms only 4.4 roots per plant (Table 2). In contrast to the variable length of roots is not verified significant difference among formulations which after 60 days of acclimatization, they have an average length of $14.5 \mathrm{~cm}$. These results are similar to those found by another

\footnotetext{
* Averages followed by the same letter in the column do not differ among them by Tukey test $(\mathrm{p}<0,005)$.
} 
research ${ }^{28}$ evaluating different substrates for acclimatization Bordô cultivar, obtained the best average roots lengths around $14.9 \mathrm{~cm}$ in Plantmax substract; however, the evaluation was performed at 36 days of ex vitro cultivation.

Longer aerial part of Bordô cv. are found when being previously cultivated in Roubelakis formulation, with $11.8 \mathrm{~cm}$, significantly differing from DSD, C2D and Galzy formulations, and did not differ from ZL formulation; ZL did not differ from DSD1 and Galzy and, finally, C2D not differ from DSD1 and Galzy (Table 2).

The IRC of acclimatized plants was lower than the values of the readings in vitro and contains no effects of culture media at this stage, possibly because the plants were subjected to the same nutrient conditions, unlike the phase in vitro (Table 2). Likewise, authors ${ }^{18}$ observed that acclimatized plants from VR043-43, VR039-16 and Paulsen 1103 grapevine rootstocks showed lower chlorophyll content in relation in vitro plants, the authors showed that these plants potentially are in the process of adaptation to new environmental conditions. Thus it is evident that according to the values of the estimates of chlorophyll in plants in vitro, are not limiting the photosynthetic operation.

After 60 days of acclimatization, the higher accumulations of total biomass were observed when Bordô cv. was previously cultivated in Roubelakis formulation, with accumulation of $219.5 \mathrm{mg}$ of dry matter, significantly differing from the C2D formulation (146.4 mg) and did not differ from ZL formulations DSD1 and Galzy, which accumulated an average of $170.4 \mathrm{mg}$ of dry matter (Table 2). This result demonstrates that the conditions of availability of nutrients from the culture media, in vitro micropropagation phase, has an influence on plant growth in the later stage of acclimatization periods, during adaptation of heterotrophic conditions. Regarding of biomass allocation in different acclimatized plant parts, the greatest accumulation occurred on the aerial part and the best results for the dry matter variable followed the same order of total biomass (Table 2).

Regarding the dry mass of the roots, the greater accumulations were found when. Bordô cv. was previously cultivated in Roubelakis formulation, forming $51.6 \mathrm{mg}$ of dry roots, differing significantly from DSD1, C2D and Galzy formulations, with average of $35.8 \mathrm{mg}$ of dry roots and did not differ from ZL formulation, which in turn is the same as the others (Table 2). The values found are in the range of 24 to $57 \mathrm{mg}$ of the dry roots accumulation defined by an important study ${ }^{28}$ in the acclimatization of. Bordô cv in different substrates.

Formulation of culture media showed effects on morphological and physiological parameters of in vitro propagation and acclimatization of grapevine Bordô cultivar. Results in this research are in agreement with those found by Roubelakis-Angelakis and Zivanovitc ${ }^{9}$ who demonstrated the influence of culture medium composition on the development of in vitro grapevine cultivars. Protocols of in vitro introduction and multiplication and acclimatization were applied successfully and showed higher indexes of survival, regeneration and rooting. 


\section{CONCLUSIONS}

In vitro propagation of Bordô cv. through nodal segments obtained from mother plants maintained in greenhouse has promoted high indexes of regeneration and rooting.

This study demonstrate that in vitro cultivation of the 'Bordô' is an efficient propagation technique due to the elevated rates of multiplication and acclimatization achieved, in additional important information was discussed there is no need of use of growth regulators in culture media to promote multiplication, rooting or specific phase for rooting of the 'Bordô'.

Considering all the analyzed variables, saline formulations Roubelakis and Zlenko has promoted better growing and development of aerial parts and roots as well the best in vitro multiplication of 'Bordô'.

\section{REFERENCES}

1. Mello LMR. Viticultura Brasileira: Panorama 2014. Embrapa Uva e Vinho, Bento Gonçalves [Comunicado técnico, 175]; 2015. Available from: http://ainfo.cnptia.embrapa.br/digital/bitstream/ item/130803/1/Comunicado-Tecnico-175.pdf

2. Camargo UA, Tonietto J, Hoffmann A. Progresso na viticultura brasileira. Revista Brasileira de Fruticultura. 2011; 33:144-9. Available from: http://dx.doi.org/10.1590/S0100-9452011000500017

3. Bettoni JC, Dalla Costa M, Gardin JPP, Kretzchmar AA, Souza JA. In Vitro propagation of Grapevine Cultivars with Potential for South of Brazil. American Journal of Plant Science. 2015; 6:1806-15. Available from: 10.4236/ajps.2015.611181

4. Melyan G, Sahakyan A, Harutyunyan A. Micropropagation of grapevine (Vitis vinifera L.) seedless cultivar 'Parvana' through lateral bud development. Vitis. 2015; 54:253-5. Available from: http:// pub.jki.bund.de/index.php/VITIS/article/view/5066/4852

5. Wang QC, Mawassi M, Li P, Tane E. Elimination of grapevine virus A (GVA) by cryopreservation of in vitro-grown shoot tips of Vitis vinifera L. Plant Science. 2003; 165:321-7. Available from: doi:10.1016/S0168-9452(03)00091-8

6. Galzy R, Haffner V, Compan D. Influence of three factors on the growth and nutrition of grapevine microcuttings. Journal of Experimental Botany. 1990; 41:295-301. Available from: 10.1093/ jxb/41.3.295

7. Krul WR, Mowbray GH. Grapes. In: Sharp WR, Evans DA, Amirato PV, Yamada Y. Handbook of plant cell culture. 1984; 6:396-434.

8. Machado MP, Biasi LA, Ritter M Ribas LLF, Koehler HS. Meios de cultura na micropropagação do porta-enxerto de videira "VR043-43" (Vitis vinifera x Vitis rotundifolia). Ciência Rural. 2007; 37:277-80. Available from: http://dx.doi.org/10.1590/S1413-70542006000400009 
9. Ayub RA, Spinardi B, Basso MF, Biasi LA. Indução de multibrotação in vitro em videira cv. Bordô. Revista Brasileira de Fruticultura. 2010; 32:675-81. Available from: http://dx.doi.org/10.1590/ $\underline{\text { S0100-29452010005000091 }}$

10. Roubelakis-Angelakis KA, Zivanovitc SB. A new culture medium for in vitro rhizogenesis of grapevine (Vitis spp.) genotypes. HortScience. 1991; 26:1551-3. Available from: http://hortsci. ashspublications.org/content/43/3/685.full.pdf + html

11. Chée R, Pool RM. In vitro vegetative propagation of Vitis: Applcation of previously defined culture conditions to a selection of genotype. Vitis. 1983; 22:363-74. Available from: http://pub.jki. bund.de/index.php/VITIS/article/view/6097

12. Silva AL, Doazan JP. Une méthode d'irradiation aux rayons gamma appliquée à des porte-greffes de vigne in vitro. Journal International des Sciences de la Vigne et du Vin. 1995; 29:1-9. Available from: http://www.scielo.br/scielo.php?script=sci nlinks\&ref=000101\&pid=S0100$\underline{-204 X 200300070000100024 \& \operatorname{lng}=p t}$

13. Zlenko VA, Troshin LP, Kotikov IV. An optimized medium for clonal micropropagation of grapevine. Vitis. 1995; 34:125-6. Available from: http://www.vitis-vea.de/admin/volltext/e039845.pdf

14. Minolta Camera Co Ltda. Manual for chlorophyll meter SPAD 502. Osaka: Minolta, Radiometric Instruments divisions; 1989.

15. Collett D. Modelling binary data. London: Chapman \& Hall; 1991.

16. R Developmment Core Team R: A language and environment for statistical computing. Vienna: R Foundation for Statistical Computing; 2014. Available from: http://www.R-project.org/

17. Villa F, Pasqual M, Pio LAS, Assis FA. Multiplicação in vitro de porta-enxerto de videira em variações do meio MS. Acta Sci. Agron. 2006; 28:345-9. Available from: 10.4025/actasciagron. v28i3.954

18. Borghezan M, Moraes LKA, Moreira FM, Silva AL. Propagação in vitro e avaliação de parâmetros morfofisiológicos de porta-enxertos de videira. Revista Brasileira de Fruticultura. 2003; 38:783-89. Available from: http://dx.doi.org/10.1590/S0100-204X2003000700001

19. Biasi LA, Passos IRS, Pommer CV. Micropropagação do porta-enxerto de videira Jales. Pesquisa Agropecuária Brasileira. 1988; 33:1587-94. Available from: http://www.hortibrasil.org.br/jnw/ images/stories/Uva/u.74.pdf

20. Silva AL, Hariscain P, Ollat N, Doazan JP. Comparative in vitro development of five grapevine rootstock varieties and mutants from the cultivar 'Gravesac'. Acta Horticulturae. 2000; 528:3517. Available from: 10.17660/ActaHortic.2000.528.49

21. Murashige T, Skoog F. A revised medium for rapid growth and bioassays with tobacco tissue cultures. Physiologia Plantarum. 1962; 15:473-97. Available from: http://priede.bf.lu.lv/grozs/ AuguFiziologijas/Augu audu kulturas MAG/literatura/03 Murashige\%20Scoog1962.pdf 
22. Barreto MS, Nookaraju A, Harini NVM, Agrawal DC. A one in vitro cloning procedure for Red Globbe grape: The influence of basal media and plant growth regulators. Journal of Applied Horticulture. 2006; 8:138-42. Available from: http://eurekamag.com/research/013/937/013937458.php

23. Mukherjee P, Husain N, Misra SC, Rao VS. In vitro propagation of a grape rootstock, deGrasset (Vitis champinii Planch.): Effects of medium compositions and plant growth regulators. Scientia Horticulturae. 2010; 126:13-9. Available from: http://www.sciencedirect.com/science/article/ pii/S0304423810002608

24. Krizan B, Ondrusiková E, Moudrá J. The effect of media composition of multiplication of grape rootstocks in vitro. Acta Universitatis Agriculturae et Silviculturae Mendelianae Brunensis. 2012; 60:141-4. Available from: http://acta.mendelu.cz/60/8/0141/

25. Guiñazú ME, Ponce MT, Guzmán J, Juárez DE, Cirrincione MA. Micropropagación de vid. Protocolo para variedades “Criollas". Rev. FCA UNcuyo. 2005; 37:93-103. Available from: http:// bdigital.uncu.edu.ar/objetos digitales/787/guinazuAgrarias2-05.pdf

26. Pôrto ML, Puiatti M, Fontes PCR, Cecon PR, Alves JC, Arruda JA. Índice SPAD para diagnóstico do estado de nitrogênio na cultura da abobrinha. Horticultura Brasileira. 2011; 29:311-5. Available from: http://dx.doi.org/10.1590/S0102-05362011000300009

27. Ribeiro DW. Morfogênese in vitro da videira: variedades Paulsen 1103, VR 043-43, Cabernet Sauvignon [dissertação]. Florianópolis: Universidade Federal de Santa Catarina - UFSC; 2006. Available from: https://repositorio.ufsc.br/handle/123456789/88374

28. Schuck MR, Lipski B, Silva ALL, Carvalho DC, Biasi LA. Aclimatização de plantas micropropagadas de videira cv. Bordô (Vitis labrusca L.) em diferentes substratos. Journal of Biotechnology and Biodiversity. 2012; 3:206-12. Available from: http://revista.uft.edu.br/index.php/JBB/article/view/394

29. Dzazio PM, Biasi LA, Zanette F. Micropropagação do prota-enxerto de videira '420-A'. Revista Brasileira de Fruticultura. 2002; 24:759-64. Available from: http://dx.doi.org/10.1590/S0100$\underline{29452002000300050}$

30. Lewandowski VT. Rooting and acclimatization of micropropagated Vitis labrusca 'Delaware'. HortScience. 1991; 26:586-9. Available from: http://hortsci.ashspublications.org/content/26/5/586.full.pdf

\section{ACKNOWLEDGEMENTS}

Thanks to the Coordination of Improvement of Higher Education (CAPES) for the scholarship award to the first author at the Graduate School. We also thanks to the Company of Agriculture Research and Rural Extension of Santa Catarina for providing the structures for execution of the work. 